\title{
Dinoflagellate infection associated with the decline of Necora puber crab populations in France
}

\author{
G. Wilhelm ${ }^{1, *}$, E. Mialhe ${ }^{2}$ \\ ${ }^{1}$ IFREMER de Lorient, 8, rue François Toullec, F-56100 Lorient, France \\ ${ }^{2}$ Université de Montpellier 2, UMR DRIM, CP 80, 2, Place Eugène Bataillon, F-34095 Montpellier Cédex 5, France
}

\begin{abstract}
Since 1984, the fishery for the velvet swimming crab Necora puber in Mor-Braz (south Brittany, Francel has declined significantly and the frequency of dying crabs found in fishery trawls and crabpots has increased. The etiology of these mortalities was investigated using histological examination of diseased crabs. A dinoflagellate parasite was found in association with pathogenic lesions of the hepatopancreas, gonads and muscles. Based on morphological features, the dinoflagellate was tentatively identified as Hematodinium sp. The presence of tissue pathology, fluctuations in crab mortality and the presence of the dinoflagellates led to the conclusion that these dinoflagellates may be the cause of the mass crab mortalities at Mor-Braz.
\end{abstract}

KEY WORDS: Hematodinium sp. - Necora puber $\cdot$ Dinoflagellate $\cdot$ Brittany

\section{INTRODUCTION}

In France, the principal fishery for the velvet swimming crab Necora puber is the Mor-Braz area of southern Brittany. Depending on the type of sea bed, crabs are caught using trawls or crabpots. Between 1984 and 1988 crab catches fell from 1100 t to $48 \mathrm{t}$, a decrease of $96 \%$. Fishing effort over the same period only decreased $60 \%$. The crab decline could not be explained by overfishing or abnormal climatic conditions. Unusual mortalities of crabs started appearing in 1986 in trawls and crabpots and during loading on boats; hence the possible role of an infectious disease was investigated.

Mass mortalities of crabs attributed to various types of infectious agents have been investigated over the last 28 yr, namely viruses (Bonami 1977, Johnson 1978, Sparks \& Morado 1987, Mari \& Bonami 1988); rickettsias (Pappalardo \& Bonami 1980, Johnson 1984, Sparks et al. 1985), bacteria (Colwell et al. 1975, Leglise \& Raguenes 1975, Johnson 1976) and protozoa (Couch 1967, 1983, Perkins 1975, Newman et al. 1976, Johnson 1977, Vivarès 1978, Armstrong et al. 1981). Particularly

\footnotetext{
•E-mail:vboulo@ifremer.fr
}

devastating epizootics have also been attributed to dinoflagellate infections, specifically of the blue crab Callinectes sapidus (Newman \& Johnson 1975) and the Alaskan Tanner crab Chionoecetes bairdi (Meyers et al. 1987, 1990, Eaton et al. 1991).

As soon as mass mortalities were reported in June 1986 from the Mor-Braz crab fishery, specimens were collected and examined histologically. This led to the discovery of a dinoflagellate infection, sometimes in association with a haplosporidian-like protozoan parasite. The morphology of the dinoflagellate and crab histopathology were examined using light and electron microscopy. In addition, the epizootiology of the disease was monitored from 1986 to 1988 to determine whether or not there was any correlation with seasonality of infection, crab maturity stage or fishing techniques. Similar investigations were conducted at the same time on fishing grounds in Spain and northwestern France.

\section{MATERIALS AND METHODS}

Crabs. Adult Necora puber were collected with trawls or crabpots from several areas in France (Fig. 1) and in Galicia, Spain. The size and the frequency of 


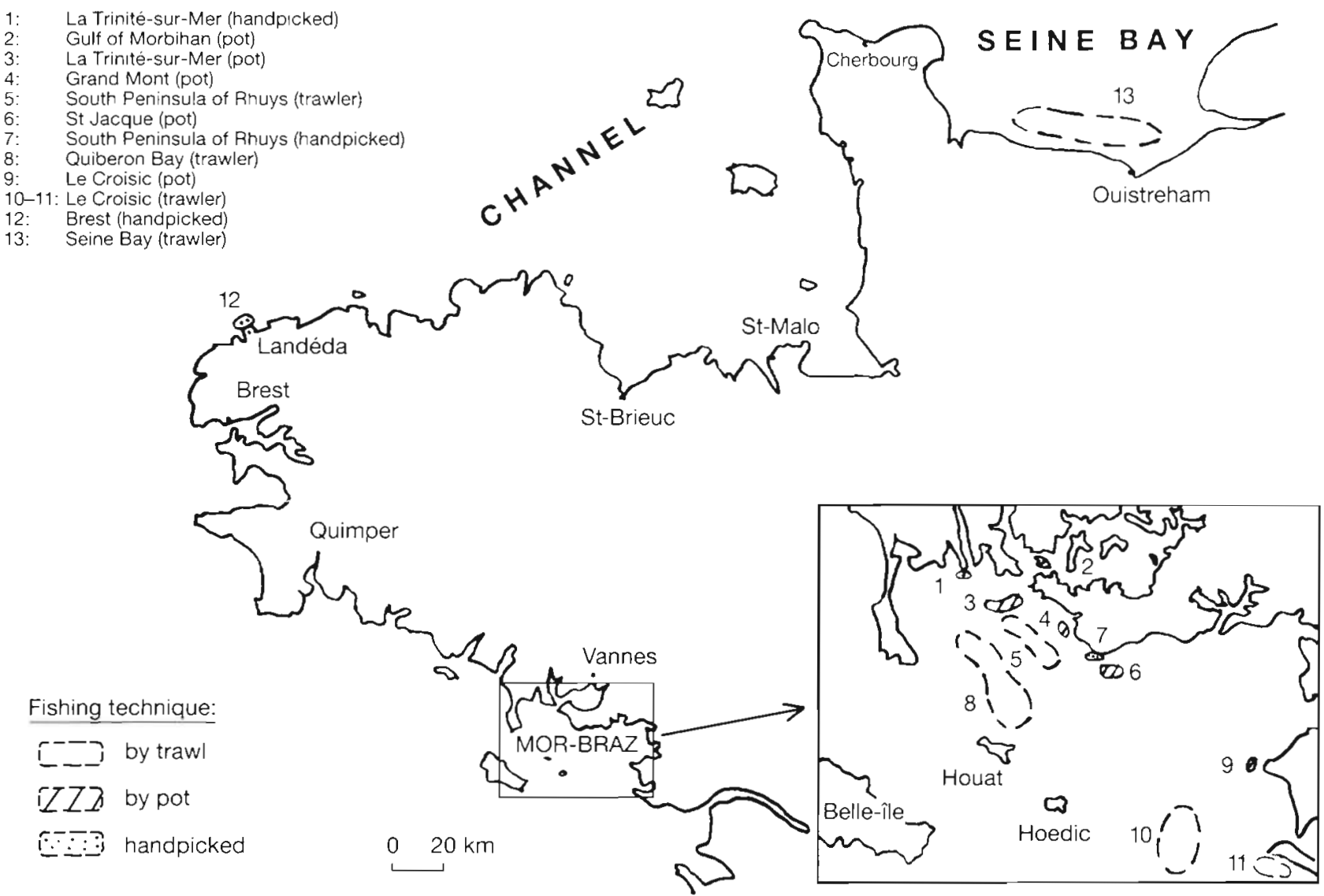

Fig. 1. Areas where Necora puber was collected in water around Brittany, France, from June 1986 to March 1988

sampling varied with geographic areas. The epizootiological survey was the most extensive in Mor-Braz (south Brittany) because of the local importance of crab fishing. Young crabs were collected by hand along the shores. Size, weight, sex and shell condition (newly molted or old shell) were noted for each crab.

Histology. Fresh hemolymph samples were withdrawn from the leg articulations and placed on a glass slide for examination using light phase microscopy.

Parasites were routinely detected in smears prepared from heart tissues which were air-dried and stained (using the Merck Hemacolor kit).

Tissues for histopathology were fixed either in Carson's fixative $(100 \mathrm{ml}$ of formol $36.5 \%, 23.4 \mathrm{~g}$ of $\mathrm{NaH}_{2} \mathrm{PO}_{4}, 2 \mathrm{H}_{2} \mathrm{O}, 5 \mathrm{~g}$ of $\mathrm{NaOH}_{1} 900 \mathrm{ml}$ of water, $\mathrm{pH}=$ 7.2) for light microscopy or, for transmission electron microscopy (TEM), in $1.25 \%$ glutaraldehyde/2\% paraformaldehyde solution in $0.1 \mathrm{M}$ sodium cacodylate buffer ( $\mathrm{pH}$ 7.4), followed by $1 \%$ osmium tetroxide in the same buffer Osmolarity was raised to $1100 \mathrm{mOsm}$ with sucrose (primary fixative) or with sodium chloride (secondary fixative). For light microscopy, samples of heart, hepatopancreas, gills and gonads were processed and embedded in paraffin; $3 \mu \mathrm{m}$ sections were stained with hematoxylin and eosin. Tissues and pelleted hemolymph samples were prepared for TEM using an automatic processor and embedded in LX 112. Thin sections (60 to $90 \mathrm{~nm}$ ) were contrasted with lead citrate and aqueous uranyl acetate by means of an LKB Ultrostainer. Grids were examined with a Jeol $1200 \mathrm{CX}$ electron microscope.

Parasite detection was performed for epidemiological surveys by light microscopy of stained heart smears. Smears were as reliable and sensitive as tissue sections, but much more rapid and easy to do, particularly for field preparation of samples.

The seasonal dynamics of this dinoflagellate disease were studied between June 1986 and 1987 using monthly sampling with trawls. Prevalence of infection was considered with individual estimations of infection intensity. No dinoflagellate counts were made. Three degrees of infection - light, moderate and high were recognized. Light infection levels meant only a few dinoflagellates were observable among crab hemocytes. In highly infected samples, dinoflagellates were predominantly or exclusively present in high numbers. In intermediate cases, the infection was classified as moderate. 


\section{RESULTS}

\section{Clinical signs}

Dying crabs showed no obvious external signs of disease with the exception of a pale pink colour of the abdomen. Creamy and yellowish hemolymph and deliquescent tissues were frequently observed internally. Such animals are unmarketable because the cooked meat has a bitter flavour, similar to the condition described for 'bitter crab disease' (Meyers et al. 1987). The characteristics of the condition are the same in France as for Tanner crabs Chionoecetes bairdi in Alaska, USA.

\section{Histopathology and parasite morphology}

Light and electron microscopy of organs from dying crabs revealed parasites invading the hepatopancreas, gonads and muscles, as well as other tissues. Severe infections caused total disorganisation of the tissues. Occasionally, haplosporidian infections were detected in heart smears.

Light microscopic examination of fresh hemolymph permitted separation of the crab hemocytes, which generally attached to the glass slide. The dinoflagellate parasites remained in suspension and appeared as refringent uninuclear or polynuclear cells. In highly infected samples, hemocytes were totally replaced by dinoflagellates.

On stained smears of hemolymph or tissues, dinoflagellate cells were 12 to $25 \mu \mathrm{m}$ in diameter with a single nucleus containing clumped or granular chromatin (Fig. 2). In multinuclear forms, nuclei frequently contained $5 \mathrm{~V}$-shaped chromosomes. Fig. 3 shows parasite cells which appear to be in the act of nuclear and cytoplasmic division. As in the uninuclear cell stages, the cytoplasm of the plasmodia was granular and vacuolated. Although 578 specimens examined were infected with parasite vegetative stages, no motile dinoflagellate spore was ever observed. In vitro attempts to induce sporulation were unsuccessful. For that purpose, $1 \mathrm{ml}$ blood from an infected crab was injected into a healthy crab.

Electron microscopy of the vegetative stages of the parasite further showed the clumped chromatin of nuclei and the nuclear membrane (Fig. 4). The vacuolated cytoplasm contained a few mitochondria but no trichocysts as have been observed in several other dinoflagellates (Bursa 1959, Bouck \& Sweeney 1966). In each month during the year, about $20 \%$ of all crabs were lightly infected by a haplosporidian species. The Haplosporidia do not seem to be pathogenic.

\section{Epizootiology}

Table 1 shows sample dates and locations (see also Fig. 1), as well as the fishing technique used, the number of individuals collected and infection prevalence. These data show that infection varied with locations as outlined below.

One sample of 42 crabs was collected from Galicia (Spain) in April 1987. Fishing of Necora puber is an important activity in this area (González-Gurriarán 1985) and no dinoflagellates were detected.

In Seine Bay (north Brittany), only 1 crab with a dinoflagellate infection was observed in samples collected during February 1987 and 1988. However, based on the epizootiological data from Mor-Braz shown below, this low rate may not necessarily be representative of dinoflagellate infection levels, since it is suspected that infected crabs die between October and January.

Dinoflagellates were observed in $7 \%$ of one sample of 44 crabs collected by hand in the Brest area (west Brittany) in February 1988.

The epizootiological survey of dinoflagellate disease was the most extensive in Mor-Braz (south Brittany) because of the local importance of crab fishing activity. Eleven sites and 46 samples ( $\mathrm{n}=9$ to 90 , depending on fishing technique) were examined.

The relationship between prevalence of infection and crab collection technique was investigated. Sample collections using trawls and crabpots were performed simultaneously in 2 neighbouring areas: one at the South of Rhuys peninsula (location 5; Fig. 1, Table 1) and one at the South of La Trinité-sur-Mer (location 3; Fig. 1, Table 1). By using Cochran or Bartlett tests (Statgraphics 1991), variances were proved to be homogeneous ( $p=0.658$ ) and variance analyses showed significant differences $(F=13.9>F 1.4=7.71$ at $5 \%$ and $F=13.9<F 1.4=21.2$ at $1 \%$ ) of infection prevalences according to fishing technique. Consequently, trawls were considered more efficient for determining infection rates since they permitted non-selective catching of active and listless crabs.

Prevalences of dinoflagellates in crab samples varied significantly by month of collection [homogeneity of variances established by Cochran and Bartlett tests (Statgraphics 1991), $\mathrm{p}=0.605$ and $\mathrm{p}=0.658$ respectively; variance analysis: $F=14.19>F 1.4$ at $5 \%$ and $F=14.19<F 1.4$ at $1 \%$ ]. Thus, fluctuations in prevalences from 10 to $80 \%$ during a 6 mo period suggested an epizootic phenomenon (Fig. 5). This hypothesis was strengthened by data related to infection intensities (Fig. 6). Indeed, the highest intensities were noted in samples taken in November and December 1986, just before a major decrease in prevalence. Consequently, it may be assumed that the death of highly infected 

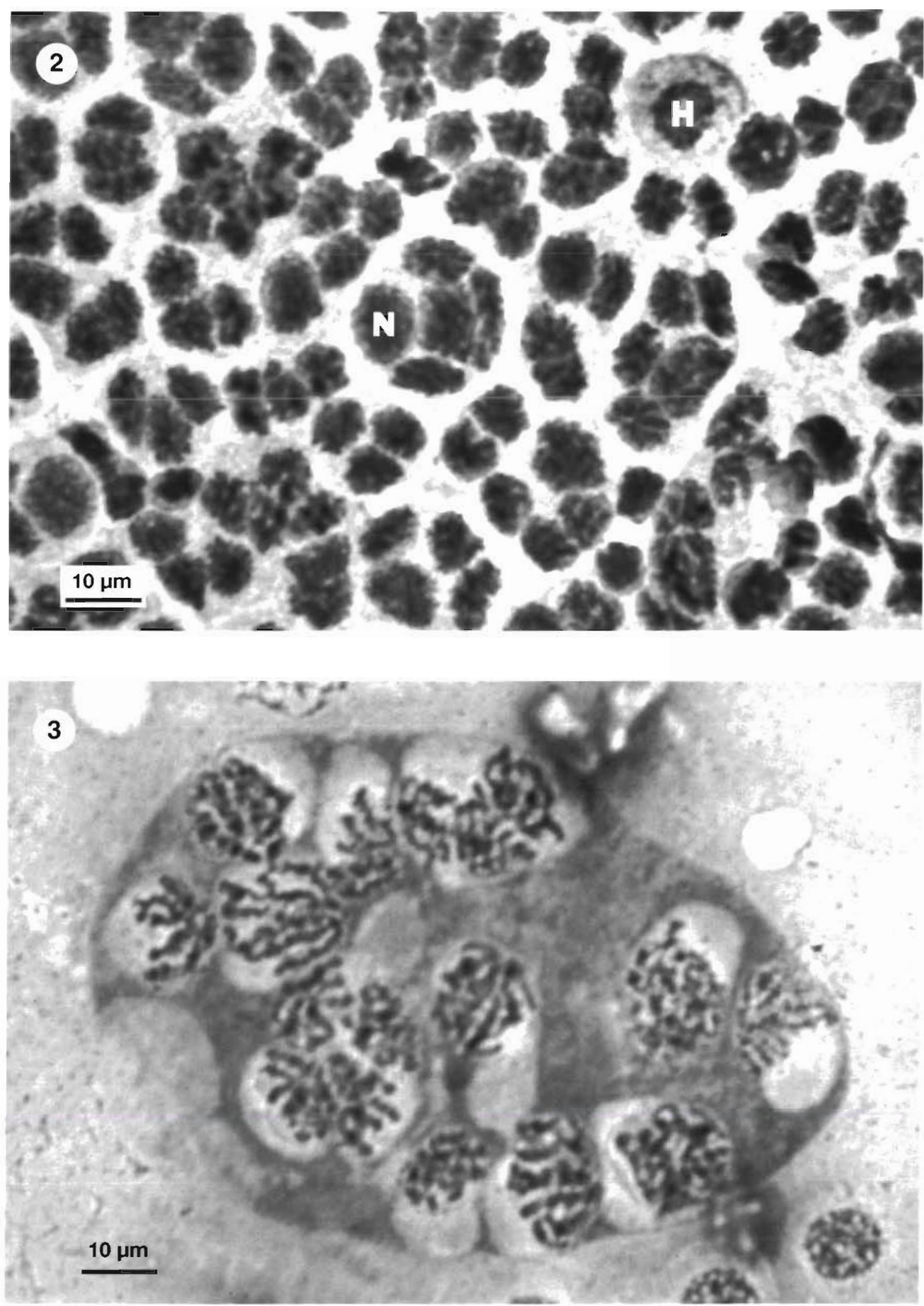

Figs. 2 \& 3. Necora puber infected by Hematodinium sp. Smear from the heart of a heavily infected crab. Fig. 2. Multiple dinoflagellate nuclei $(\mathrm{N})$ in plasmodia are compact and host hemocytes $(\mathrm{H})$ are very rare. Fig. 3 . Dividing nuclei showing chromosomes surrounded by a white, curcular zone 


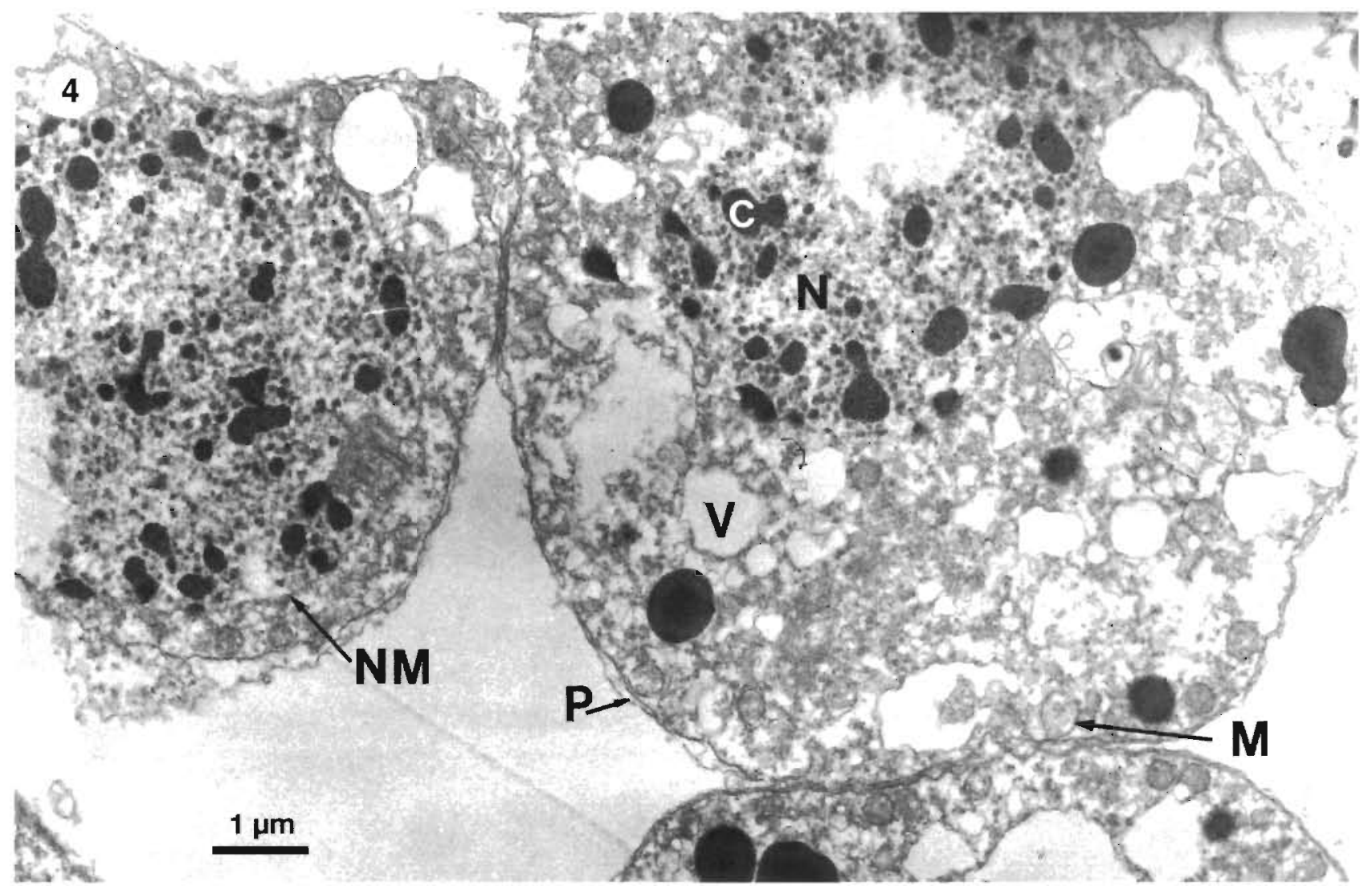

Fig. 4. Necora puber infected by Hematodinium sp. Typical dinoflagellate vegetative stage from the hemolymph of an infected crab. Transmission electron micrograph. The nucleus $(N)$ is large, with dense chromatin surrounded by a membrane (NM). The cytoplasm contains polymorphic vacuoles ( $V$ ) of different sizes. There are few mitochondria (M). A pellicle (P) borders the dinoflagellate cell

crabs led to the subsequent decrease in prevalence. Such a hypothesis concurs with observations of fishers who have found many dead crabs during winter.

In samples of adult crabs collected in June and July $1986,34 \%$ had a soft shell indicating that they were newly molted. About $43 \%$ of these soft-shell crabs

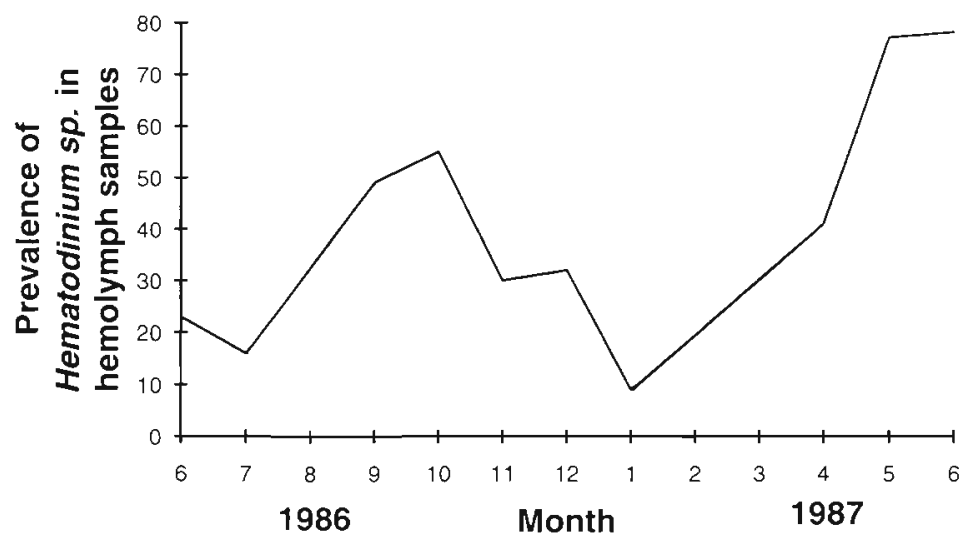

Fig. 5. Monthly prevalence of Hematodinium sp. infection in Necora puber collected by trawl during 1986 and 1987 from Mor-Braz, France were infected compared to only $14 \%$ in hard-shell crabs. This difference in prevalence was statistically significant $\left(\chi^{2}\right.$ test $=7.4>3.84$ at $5 \%$ ).

No relationship was found between infection prevalence and sex or size of crabs. However, $47 \%$ of the smallest crabs examined ( 15 to $20 \mathrm{~mm}$ carapace width) manually collected in February 1987 from La Trinité shores were found to be infected. This shows that at any age, crabs can be infected.

\section{DISCUSSION}

In Brittany, fishing for molluscs and crabs is a traditional and economically important activity which has been severely depressed by epizootics over the last $20 \mathrm{yr}$.

The parasite studied here is related to the genus Hematodinium (Dinoflagellata: Syndinidae) on the basis of morphological and ultrastructural characteristics of uninuclear 

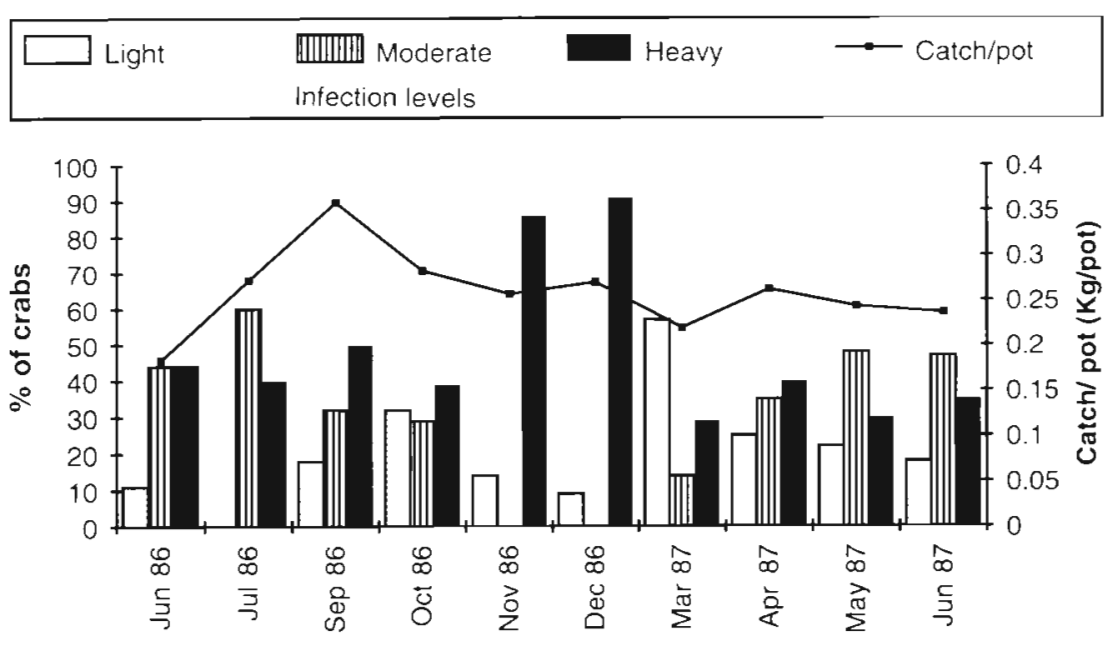

Fig. 6. Monthly intensity of Hematodinium sp. infection in Necora puber collected by trawl during 1986 and 1987 from Mor-Braz, compared to catch per rrah not cells and plasmodia (Chatton \& Poisson 1931, Newman \& Johnson 1975, MacLean \& Ruddell 1978). This dinoflagellate differed from a similar Hematodinium parasite observed in a sympatric crab, Cancer pagurus (Latrouite 1988), in that it lacked trichocyst organelles.
This difference may be species-related, or it might have been due to the season of the investigation. The disease caused by a Hematodinium dinoflagellate in Necora puber appears similar to dinoflagellate-caused diseases described from blue crab Callinectes sapidus

Table 1. Percentage of Hematodinium dinoflagellate infection of Necora puber in relation to date, fishing method and the areas of collection (numbers in parentheses refer to loctions in Fig. 1). Fishing methods: $T$, trawler; $H$, handpicked; $P$, pot; SP, shrimp pot

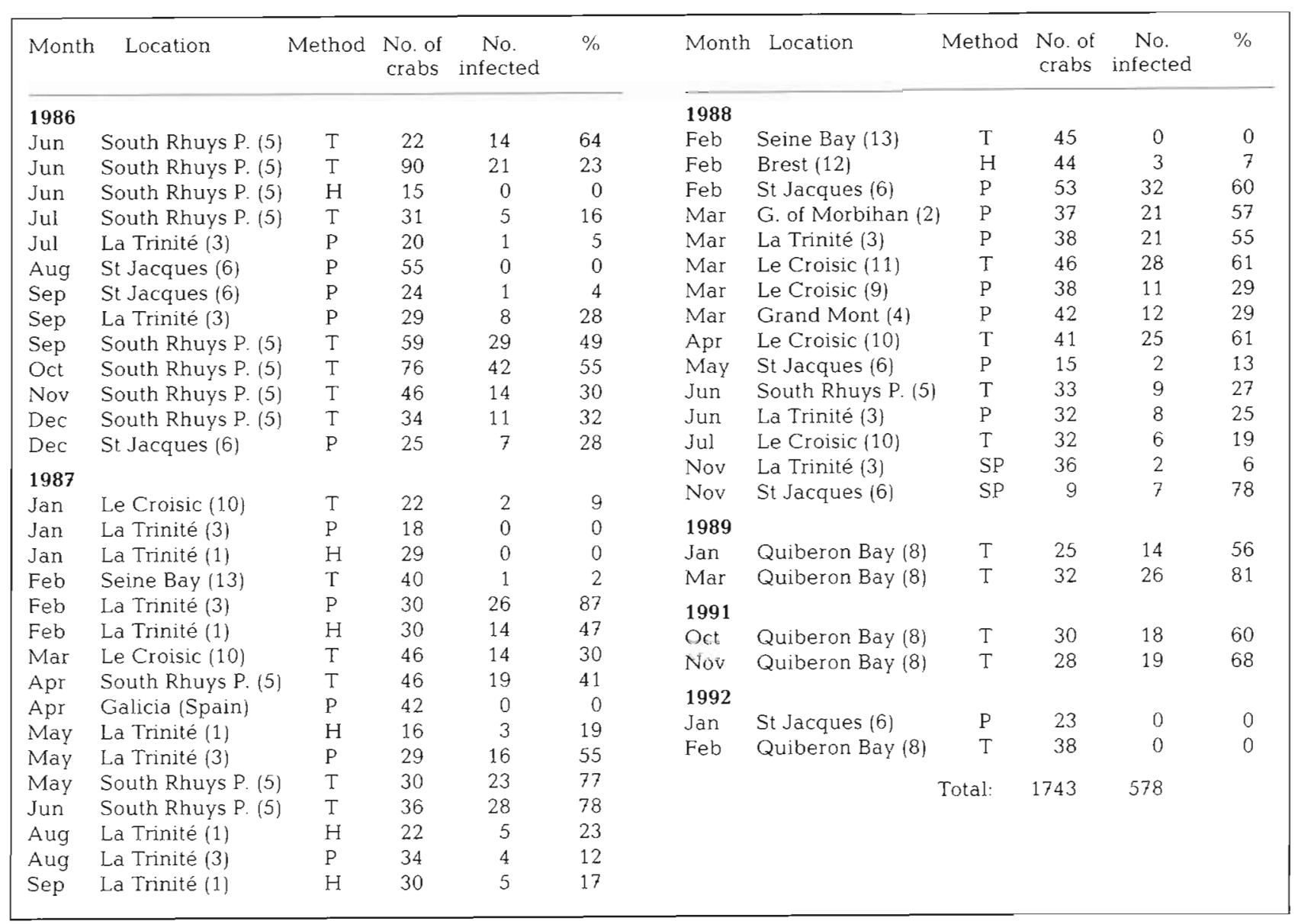


and the Alaskan Tanner crab Chionoecetes bairdi (Meyers et al. 1987, Eaton et al. 1991). To better understand the taxonomical relationships between these parasites, morphological data will have to be complemented by biochemical and immunological characterizations.

Crab collection by trawl proved better than pots for reliably determining infection prevalences. Crabs were caught independently of their activity, which is strongly decreased in the final stages of the disease.

It is noteworthy that minimal infection prevalences followed the disappearance of the crabs with the greatest infection intensities; this disappearance coincided with mass crab mortalities. The histopathological and epizootiological data together reinforce the probability that this dinoflagellate infection caused the drop in crab production in Mor-Braz. The periodicity of the disease and a possible seasonal correlation have yet to be clearly defined, as has recently been done for a similar disease in the Alaskan Tanner crab (Meyers et al. 1987, Eaton et al. 1991). The infection process will also have to be determined, considering that prevalences were higher in newly molted crabs and that only vegetative stages were observed. It is probable that the soft crab stage is more susceptible to infection by the infective stage of the dinoflagellate.

These data reinforce previous information related to the role of dinoflagellates as regulators of crab populations. Thus, it appears crucial to develop epizootiological surveys to anticipate the risks of epizootics and to appropriately manage the fishery around such occurrences

Acknowledgements. The authors are most grateful to S. E McGladdery for reviewing the manuscript.

\section{LITERATURE CITED}

Armstrong DA, Burreson EM, Sparks AK (1981) A ciliate infection Paranophrys sp. in laboratory-held Dungeness crabs, Cancer magister. J Invertebr Pathol 37:201-209

Bonami JR (1977) Les maladies virales des crustacés et des mollusques. Océanis 3:5

Bouck GB, Sweeney $M$ (1966) The fine structure and ontogeny of trichocysts in marine dinoflagellates. Protoplasma 61:205-223

Bursa A (1959) The genus Prorocentrum Ehrenberg, morphodynamics, protoplasmic structures, and taxonomy. Can J Bot 37:1-31

Chatton E, Poisson R (1931) Sur l'existence dans le sang des crabes, de Péridiniens parasites: Hematodinium perezi (Syndinidae). Cr Séances Soc Biol Strasbourg 105:553-557

Colwell RR, Wicks TC, Tubiash HS (1975) A comparative study of the bacterial flora of the hemolymph of Callinectes sapidus. Mar Fish Rev 37(5-6):29-33

Couch JA (1967) A new species of Lagenophrys (Ciliatea: Peritrichida: Lagenophrydae) from a marine crab, Callinectes sapidus. Trans Am Microsc Soc 86(2)

Couch JA (1983) Diseases caused by Protozoa. In: The biology of crustacea, Vol 6. Academic Press, p 79-108
Eaton WD, Love DC, Botelho C, Meyers TR, Imamura K, Koeneman T (1991) Preliminary results on the seasonality and the life cycle of the parasitic dinoflagellate causing bitter crab disease in Alaskan tanner crabs Chionoecetes bairdi. J Invertebr Pathol 57:426-434

González-Gurriarán E (1985) Reproduccion de la necora Macropipus puber (L.) (Decapoda, Brachyura), y ciclo reproductivo en la Ria de Arousa (Galicia, N/W Espana). Bol Inst Esp Oceanogr 2(1):33-51

Johnson PT (1976) Bacterial infection in the blue crab, Callinectes sapidus: course of infection and histopathology. $\mathrm{J}$ Invertebr Pathol 28:25-36

Johnson PT (1977) Paramoebiasis in the blue crab, Callinectes sapidus. J Invertebr Pathol 29:308-320

Johnson PT (1978) Viral diseases of the blue crab, Callinectes sapidus. Mar Fish Rev 40:13-15

Johnson PT (1984) A rickettsia of the blue king crab, Paralithodes platypus. J Invertebr Pathol 44:112-113

Latrouite D, Morizur Y, Noel P, Chagot D, Wilhelm G (1988) Mortalité du tourteau Cancer pagurus provoquée par le dinoflagellé parasite Hematodinium sp. Comm Meet Int Coun Explor Sea CM-ICES/K32:E (Shellfish and Benthos Comm)

Leglise M, Raguenes G (1975) Note préliminaire sur une maladie du crabe Cancer pagurus due à une bactérie du genre Aeromonas. Comm Meet Int Coun Explor Sea CMICES/K36:E (Shellfish and Benthos Comm)

MacLean SA, Ruddell MC (1978) Three new crustacean hosts for the parasitic dinoflagellate Hematodinium perezi (Dinoflagellata: Syndinidae). J Parasitol 63:554-557

Mari J, Bonami JR (1988) PC 84, a parvo-like virus from the crab Carcinus mediterraneus: pathological aspects, ultrastructure of the agent, and first biochemical characterization. J Invertebr Pathol 51:145-156

Meyers TR, Botelho C, Eaton W, Koeneman TM, Imamura K (1990) Distribution of bitter crab dinoflagellate syndrome in Alaskan Tanner crabs Chionoecetes bairdi. Dis Aquat Org 9:37-43

Meyers TR, Koeneman TM, Botelho C, Short S (1987) Bitter crab disease: a fatal dinoflagellate infection and marketing problem for Alaskan Tanner crabs Chionoecetes bairdi. Dis Aquat Org 3:195-216

Newman MW, Johnson CA (1975) A disease of blue crabs (Callinectes sapidus) caused by a parasitic dinoflagellate. Hematodinium sp. J Parasitol 63:554-557

Pappalardo R, Bonami JR (1980) Étude histopathologique et ultrastructurale d'une maladie rickettsienne chez le crabe Carcinus mediterraneus Czerniavski (Crustacé Décapode). Rev Trav Inst Pêches Marit 44(3):277-283

Perkins FO (1975) Fine structure of Minchinia sp. (Haplosporida). Sporulation in the mud crab, Panopeus herbstii Mar Fish Rev 37:5-6

Sparks AK, Morado JF (1987) A herpes-like virus disease in the blue king crab Paralithodes platypus. Dis Aquat Org $1: 115-122$

Sparks AK, Morado JF, Hawkes JW (1985) A systemic microbial disease in the Dungeness crab, Cancer magister, caused by a chlamydia-like organism. J Invertebr Pathol $45: 204-217$

Statgraphics (1991) Statistical graphics system, Version 5 , Reference manual. Statistical Graphics Corporation, Rockville, MD

Vivarès CP (1978) Grégarinoses et microsporidioses e Brachyoures (Crustacés, Décapodes) de la Méditerranée occidentale: aspects cytologiques, biochimiques et physiologiques. Thèse de Doctorat, Univ Sci Techn du Languedoc, Montpellier 